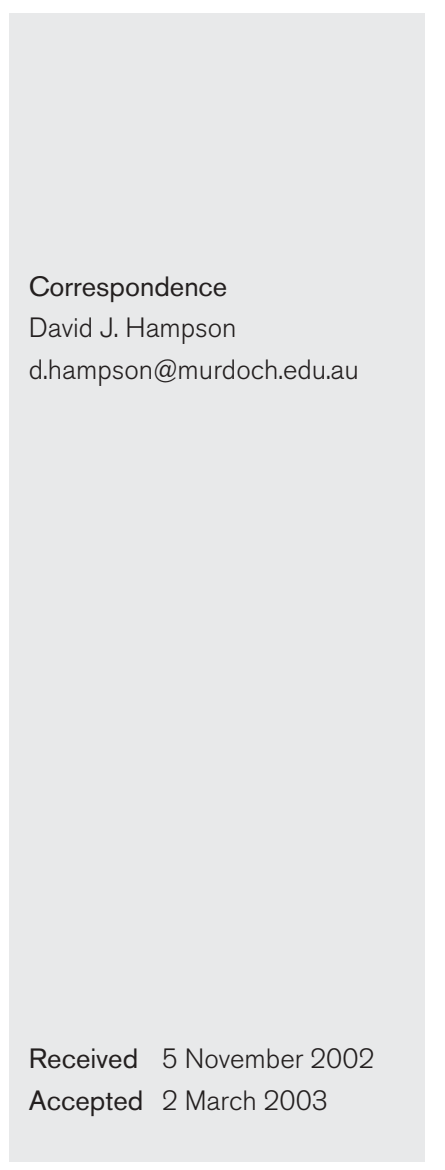

\title{
Evaluation of selective media for the isolation of Brachyspira aalborgi from human faeces
}

\author{
C. Josephine Brooke, ${ }^{1}$ Thomas V. Riley ${ }^{2,3}$ and David J. Hampson ${ }^{1}$ \\ ${ }^{1}$ Division of Veterinary and Biomedical Sciences, Murdoch University, Murdoch, Western Australia \\ 6150, Australia \\ ${ }^{2,3}$ Division of Microbiology and Infectious Diseases, The Western Australian Centre of Pathology and \\ Medical Research ${ }^{2}$ and Department of Microbiology, The University of Western Australia ${ }^{3}$, \\ Nedlands, Western Australia 6009, Australia
}

\begin{abstract}
The purposes of this study were to identify a solid medium that supports improved growth of the anaerobic intestinal spirochaete Brachyspira aalborgi, to modify this for use as a selective isolation medium and then to test the medium for its effectiveness in isolating $B$. aalborgi from patients' faeces. Of the media evaluated, brain heart infusion agar (BHIA) with $10 \%$ bovine blood (BB) was the most effective base-supplement combination for growth, with colonies attaining $1.2 \mathrm{~mm}$ in diameter by 21 days. Incubation in an anaerobic jar $\left(94 \% \mathrm{H}_{2}, 6 \% \mathrm{CO}_{2}\right)$ permitted growth of larger colonies than incubation in an anaerobic chamber $\left(80 \% \mathrm{~N}_{2}, 10 \% \mathrm{H}_{2}, 10 \% \mathrm{CO}_{2}\right)$. Growth was improved only slightly at $38.5^{\circ} \mathrm{C}$ compared with $37^{\circ} \mathrm{C}$. Selection of $B$. aalborgi from artificially seeded faeces was achieved equally well on eight different solid media containing spectinomycin $\left(400 \mu \mathrm{g} \mathrm{ml}^{-1}\right)$ alone or in combinations with polymyxin B $\left(5 \mu \mathrm{g} \mathrm{ml}^{-1}\right)$, colistin $\left(25 \mu \mathrm{g} \mathrm{ml}^{-1}\right)$ and rifampicin $\left(12.5 \mu \mathrm{g} \mathrm{ml}^{-1}\right.$ ). By using BHIA $10 \% \mathrm{BB}$ with spectinomycin plus polymyxin $\mathrm{B}, \mathrm{B}$. aalborgi was isolated from one of five human faecal samples that were positive for $B$. aalborgi by PCR amplification. This is the first report of the isolation of $B$. aalborgi from human faeces.
\end{abstract}

\section{INTRODUCTION}

The anaerobic intestinal spirochaetes Brachyspira aalborgi and Brachyspira pilosicoli both colonize the large intestine of humans (Hovind-Hougen et al., 1982; Trivett-Moore et al., 1998). Both have also been associated with a condition called 'intestinal spirochaetosis', in which spirochaetes may be found attached by one cell end to the colorectal epithelium, forming a 'false brush border' (Harland \& Lee, 1967; Mikosza \& Hampson, 2001). Extensive colonization has been reported to result in a variety of intestinal disturbances, including chronic diarrhoea, abdominal pain and rectal bleeding (Gad et al., 1977; Crucioli \& Busuttil, 1981; Douglas \& Crucioli, 1981; Padmanabhan et al., 1996; Peghini et al., 2000).

Of the two spirochaete species, B. aalborgi is the more slowly growing and fastidious, requiring at least 2-3 weeks for isolation (Hovind-Hougen et al., 1982). Consequently, $B$. aalborgi has been relatively poorly studied and detection has relied on the use of PCR amplification of B. aalborgi DNA from colorectal biopsies (Mikosza et al., 1999, 2001a; Kraaz et al., 2000) or faeces (Mikosza et al., 2001b). Isolation of $B$. aalborgi has been reported only three times, in each case following culture of fresh colonic biopsy specimens taken

Abbreviations: BB, bovine blood; BHIA, brain heart infusion agar. from Scandinavian patients (Hovind-Hougen et al., 1982; Kraaz et al., 2000; Jensen et al., 2001). The isolation medium in these studies was tryptose soy agar supplemented with $10 \%$ bovine blood (BB), containing $400 \mu \mathrm{g}$ spectinomycin and $5 \mu \mathrm{g}$ polymyxin $\mathrm{ml}^{-1}$. To date, $B$. aalborgi has not been isolated from human faeces, although the organism was recently isolated from the faeces of captive non-human primates (Munshi et al., 2003). The lack of isolates has hampered comprehensive characterization and pathogenicity studies with this organism.

The purposes of the current study were to identify a solid medium that enhanced the growth of B. aalborgi, to modify this as an improved isolation medium and then to use it to isolate B. aalborgi from the faeces of human patients.

\section{METHODS}

Strategy for media development. The strategy followed was to test two laboratory-adapted reference strains of B. aalborgi for their growth on a range of agar bases, initially supplemented with $10 \% \mathrm{BB}$ as for the original isolation medium (Hovind-Hougen et al., 1982). The base that supported the best growth then was tested with different primary supplements (blood) and the optimal combination was then tested with different secondary supplements and under different environmental conditions. To make the medium selective for B. alborgi, a range of potentially inhibitory substances was evaluated, using human faeces 
seeded with the B. aalborgi strains. Finally, the optimized isolation medium was tested on the faeces of human patients.

Reference strains and preparation of inocula. B. aalborgi strains $513 \mathrm{~A}^{\mathrm{T}}$ (=ATCC $43994^{\mathrm{T}}$ ) (Hovind-Hougen et al., 1982) and W1 (Kraaz et al., 2000) were obtained from the culture collection held at the Reference Centre for Intestinal Spirochaetes at Murdoch University. The reference strains were routinely cultured on Columbia base agar containing $6 \%$ equine blood (BA), incubated for 10 days at $37^{\circ} \mathrm{C}$ in an anaerobic jar with an atmosphere of $94 \% \mathrm{H}_{2}$ and $6 \% \mathrm{CO}_{2}$ generated with a Gaspak Plus envelope (BBL). For media assessment, spirochaete growth was resuspended in PBS or Brucella broth using a sterile cottontipped swab and the suspension was returned to anaerobic conditions until inoculation. The organisms were counted in a Helber counting chamber, the concentration was adjusted to $1 \times 10^{8}$ organisms ml ${ }^{-1}$ and their viability was assessed by inoculation on BA using the spread plate method. Volumes of $50 \mu \mathrm{l}$ were added to plates and the suspensions were streaked for single colonies in a standard manner.

Growth media. The following agar bases, all acquired from Oxoid, were used in the study: brain heart infusion agar (BHIA), Columbia base agar, Brucella base agar plus vitamin $\mathrm{K}\left(1 \mathrm{mg} \mathrm{ml}^{-1}\right)$ and haemin (5 $\mathrm{mg} \mathrm{ml}^{-1}$ ), Wilkins-Chalgren agar and anaerobe basal agar. In addition, trypticase soy agar (TSA) from Becton Dickinson was used by itself and as a base for a modification of Kunkle's broth medium (Kunkle et al., 1986). The latter contained $2 \%$ fetal calf serum (FCS), $1.5 \%$ alcoholic cholesterol solution, $1 \%(\mathrm{w} / \mathrm{v})$ yeast extract, $0.5 \%(\mathrm{w} / \mathrm{v})$ glucose, $0 \cdot 2 \%(\mathrm{w} / \mathrm{v}) \mathrm{NaHCO}_{3}$ and $0 \cdot 05 \%(\mathrm{w} / \mathrm{v})$ cysteine hydrochloride monohydrate. Primary supplements that were tested with each of the agar bases were 5 and $10 \%$ ovine blood (OB), $10 \% \mathrm{BB}$ and $10 \%$ defibrinated BB. Secondary supplements were $2 \%$ FCS, $1.5 \%$ ethanolic cholesterol solution and $5 \%$ pig faeces extract. The latter was prepared by emulsifying one part faeces obtained from normal adult pigs that had not received antimicrobials in four parts sterile PBS, stirring the emulsion for $24 \mathrm{~h}$ at $4{ }^{\circ} \mathrm{C}$ and then centrifuging for $1 \mathrm{~h}$ at $9950 \mathrm{~g}$ at $4{ }^{\circ} \mathrm{C}$. The supernatant was stored at $-20{ }^{\circ} \mathrm{C}$ until required and filtersterilized $(450 \mathrm{~nm})$ before being added to agar.

Additional parameters assessed included $30 \mathrm{~min}$ pre-reduction of the plates prior to inoculation and incubation either in an anaerobic jar using the Gaspak Plus system or in an anaerobic chamber $\left(80 \% \mathrm{~N}_{2}\right.$, $10 \% \mathrm{H}_{2}, 10 \% \mathrm{CO}_{2}$ ) (Don Whitley Scientific). Growth in anaerobic jars was compared at $37,38.5$ and $42^{\circ} \mathrm{C}$. The influence of $\mathrm{pH}$ was assessed by adding $4 \mathrm{ml} 10 \mathrm{mM} \mathrm{KCl}$ to $2 \mathrm{ml}$ set TSA $10 \%$ BB (Carson et al., 2000) and the $\mathrm{pH}$ was measured after $30 \mathrm{~min}$ incubation at room temperature. BA was used as a control medium in all tests.

Isolation media. The susceptibility of $B$. aalborgi strains to a range of antimicrobials for potential use as selective agents was determined with Microring MWAC and MWAN discs (Medical Wire \& Equipment). The selective compounds and their disc strengths are listed in Table 1. In addition, spectinomycin $(\mathrm{S})$, vancomycin $(\mathrm{V})$, colistin $(\mathrm{C})$, rifampicin (R) and polymyxin B (P) (Sigma) were incorporated directly into the media. Susceptibility to bile (dried ox bile, pure for microbiology; Merck) was assessed by making bile discs containing 5, 10 or $15 \mathrm{mg}$ bile (Weinberg et al., 1983) and placing these on BA swabbed with the suspensions.

The selective capacity of the media was examined by adding $1 \mathrm{ml}$ bacterial suspension $\left(10^{8}\right.$ cells) to $1 \mathrm{~g}$ faeces from a healthy donor who had been confirmed free of B. aalborgi and B. pilosicoli by faecal PCR. The suspension was mixed thoroughly and $10 \mu \mathrm{l}$ was added to a plate with a standard loop and streaked as above. Selection of B. aalborgi from seeded faeces was tested on TSA $10 \%$ BB with all combinations of spectinomycin $\left(400 \mu \mathrm{g} \mathrm{ml}^{-1}\right)$, vancomycin $\left(25 \mu \mathrm{g} \mathrm{ml}^{-1}\right)$ and colistin $\left(25 \mu \mathrm{g} \mathrm{ml}^{-1}\right)$. Additionally, spectinomycin $\left(400 \mu \mathrm{g} \mathrm{ml}^{-1}\right)$ plus all combinations of polymyxin B $\left(5 \mu \mathrm{g} \mathrm{ml}^{-1}\right)$, rifampicin $\left(12.5 \mu \mathrm{g} \mathrm{ml}^{-1}\right)$
Table 1. Compounds tested for use in development of selective media for $B$. aalborgi

\begin{tabular}{|lc|}
\hline Compound & Concentration \\
\hline Added to agar & \\
Spectinomycin & $400 \mu \mathrm{g} \mathrm{ml}^{-1}$ \\
Vancomycin & $25 \mu \mathrm{g} \mathrm{ml}^{-1}$ \\
Colistin & $25 \mu \mathrm{g} \mathrm{ml}^{-1}$ \\
Polymyxin B & $5 \mu \mathrm{g} \mathrm{ml}^{-1}$ \\
Rifampicin $^{-1}$ & $12 \cdot 5 \mu \mathrm{g} \mathrm{ml}^{-1}$ \\
Discs $^{\star}$ & \\
Ox bile $^{a}$ & 10 and $15 \mathrm{mg}$ \\
Novobiocin $^{b}$ & $5 \mu \mathrm{g}$ \\
Erythromycin $^{c}$ & $60 \mu \mathrm{g}$ \\
Kanamycin $^{c}$ & $1000 \mu \mathrm{g}$ \\
Colisitin $^{c}$ & $10 \mu \mathrm{g}$ \\
Metronidazole $^{b}$ & $5 \mu \mathrm{g}$ \\
${\text { Penicillin } \mathrm{G}^{c}}_{\text {Rifampicin }^{c}}$ & $2 \mathrm{IU}$ \\
Sodium polyethol sulfonate $^{b}$ & $15 \mu \mathrm{g}$ \\
Vancomycin $^{c}$ & $1 \mathrm{mg}$ \\
\hline
\end{tabular}

${ }^{*}$ Compounds were tested as discs prepared in-house $(a)$ or were contained in Microring MWAC (b) or Microring MWAN (c) discs in the amounts shown.

and colistin $\left(25 \mu \mathrm{g} \mathrm{ml}^{-1}\right)$ was tested. The lower limit of selection of $B$. aalborgi from seeded faeces on spectinomycin plus polymyxin B (SP) was determined by performing 10 -fold dilutions on the bacterial suspension. Faeces were seeded, mixed and streaked as above.

Both growth and isolation mediawere examined for B. aalborgiafter 10, 14, 18 and 21 days incubation. Growth was assessed by recording colony size and scoring the extent of growth along streaks on the test plates. A grading method was developed where the best medium was scored ' 1 ' at a given time-point, thenextbestmedium '2' and soon, and ameanwasdetermined for each medium after 21 days. All procedures were repeated at least once.

Isolation. The efficacy of the best medium was tested by attempting isolation of B. aalborgi from fresh faecal samples from 60 apparently healthy individuals taking part in a study examining carriage of intestinal spirochaetes, using faecal PCR as described by Mikosza et al. (2001b). Five of these individuals had positive faecal PCRs for $B$. aalborgi (data not shown). Isolation of $B$. aalborgi was attempted on BHIA $10 \%$ BB SP, incubated in an anaerobic jar at $37^{\circ} \mathrm{C}$ for 21 days before being exposed to oxygen. Spirochaete growth was subcultured to $\mathrm{BA}$ and colonial and phase-contrast morphologies were recorded. For electron microscopy, the cultured spirochaetes were scraped from the plates and resuspended in distilled water. Drops of the suspensions were placed on Formvar-coated reinforced grids and stained with phosphotungstic acid $(3 \%, \mathrm{pH} 7 \cdot 2)$. Grids were examined in a Philips CM100 Biotwin transmission electron microscope.

Spirochaete identity was confirmed by adding cells directly to PCRs designed to amplify portions of the 16S rRNA genes of B. aalborgi or $B$. pilosicoli (Mikosza et al., 1999, 2001a). Cycling for B. aalborgi was carried out at an annealing temperature of $48^{\circ} \mathrm{C}$. The PCR product was sequenced in both directions using a commercially available cycle sequencing kit (ABI PRISM BigDye dye terminator cycle sequencing ready reaction kit, version 1.0; Applied Biosystems), according to the manufacturer's instructions. The sequence was analysed on the ABI 
PRISM 310 Genetic Analyzer (Applied Biosystems). The sequence data obtained were aligned and compared with $16 \mathrm{~S}$ rDNA sequences of the $B$. aalborgi and B. pilosicoli type strains by BLAST search with the National Centre for Biotechnology Information server at the National Library of Medicine. Multiple sequence alignments were performed by the CLUSTAL method using BioManager with the Angis server.

\section{RESULTS}

\section{Growth media}

The most effective agar base for B. aalborgi growth was BHIA with $10 \% \mathrm{BB}$. After 21 days, colonies on this medium were $1.2 \mathrm{~mm}$ in diameter, light grey and weakly $\beta$-haemolytic. A diameter of $1 \mathrm{~mm}$ was attained after 14 days incubation. The next best growth was on TSA with $10 \% \mathrm{BB}$, on which colonies only reached $0.8 \mathrm{~mm}$ diameter and had a transparent appearance. All the other bases supported growth, but colonies were small and slow to appear.

As a supplement, $10 \% \mathrm{BB}$ was superior to $10 \% \mathrm{OB}$, which, in turn, allowed larger colonies and faster growth than $5 \% \mathrm{OB}$, where a maximum size of only $0.5 \mathrm{~mm}$ was achieved after 21 days. Additional supplements of $2 \%$ FCS, $1.5 \%$ cholesterol and $5 \%$ pig faecal extract offered no growth advantage. Defibrination of $\mathrm{BB}$ or pre-reduction of the media did not improve growth of $B$. aalborgi. Growth of B. aalborgi did not occur at $42{ }^{\circ} \mathrm{C}$. Colonies on BHIA incubated at $38.5{ }^{\circ} \mathrm{C}$ were at best only $0.2 \mathrm{~mm}$ larger at some time-points than colonies on BHIA incubated at $37^{\circ} \mathrm{C}$. The best $\mathrm{pH}$ for growth of $\mathrm{B}$. aalborgi on TSA $10 \% \mathrm{BB}$ was $\mathrm{pH}$ 7. Growth to $\mathrm{pH} 8$ was satisfactory, but agar below pH 6.5 would not withstand prolonged incubation. The $\mathrm{pH}$ of BHIA $10 \% \mathrm{BB}$ was $7 \cdot 6$. For all media, incubation in an anaerobic jar resulted in growth of larger colonies, by $0 \cdot 2-0.5 \mathrm{~mm}$, compared with incubation in an anaerobic chamber.

\section{Selective media}

Both reference strains of B. aalborgi were susceptible to bile, metronidazole, penicillin $\mathrm{G}$, kanamycin and vancomycin and resistant to spectinomycin, polymyxin B, colistin, erythromycin and rifampicin. Equivocal results were obtained for sodium polyethol sulfonate and novobiocin for strain $\mathrm{W} 1$, while strain $513 \mathrm{~A}^{\mathrm{T}}$ was susceptible to these compounds. On media with antimicrobials incorporated, clear growth of $B$. aalborgi occurred on all plates except those containing vancomycin, although colonies were frequently $0.2 \mathrm{~mm}$ smaller than on the medium without antimicrobials. Selection of B. aalborgi from seeded faeces was achieved on media containing S, SP, SC, SR, SRC, SPR, SPC and SRPC, and no single medium produced consistently superior growth. The lower limit of detection of $B$. aalborgi from seeded faeces on SP was around 200 c.f.u. per $10 \mu$ seeded faeces or $2 \times 10^{4}$ c.f.u. $\mathrm{g}^{-1}$.

Spirochaetes were isolated from one of the five faecal samples that were previously shown by PCR to contain $B$. aalborgi. After 21 days incubation, two types of weakly $\beta$-haemolytic colonies were seen on BHIA $10 \%$ BB: these were grey, spreading colonies of $1.2 \mathrm{~mm}$ diameter with a raised, pinpoint centre inside an irregular flat edge (type A) or smooth, pinpoint colonies $(<0 \cdot 1 \mathrm{~mm}$ diameter) (type B). On subculture, a mixture of the two colony types persisted; however, the type A colonies predominated.

\section{PCR and sequencing}

PCR of both colony types from the primary isolation plate confirmed their identity as B. aalborgi. A band of $472 \mathrm{bp}$ corresponding to the expected product size in the B. aalborg $i$ $16 \mathrm{~S}$ rRNA PCR was obtained, while no band was obtained in a 16S rRNA PCR for B. pilosicoli. Sequencing of the PCR product from each colony type showed $99 \%$ similarity with the sequences for $B$. alborgi $513^{\mathrm{T}}$, W1 and nine of the uncultured Brachyspira isolates sequenced by Pettersson et al. (2000). For each colony type, polymorphisms occurred at the base equivalent to position 416 in Escherichia coli (Brosius et al., 1978), where a guanidine residue was replaced by thymidine, and at the base equivalent to position 436, where thymidine was replaced by cytosine.

\section{Phase-contrast and electron-microscope morphology}

Under the phase-contrast microscope, the spirochaetes appeared as short, helical cells with a pronounced flexuous motility. Cells from the two colony types had a similar appearance. Electron microscopy revealed two cell types. One was a plump cell type, varying from $2 \cdot 0$ to $6.0 \mu \mathrm{m}$ long and about $250 \mathrm{~nm}$ wide. Cells were typically ' $\mathrm{S}$ '- or commashaped with a $2 \mu \mathrm{m}$ wavelength. The other cell type was similar in length, shape and amplitude, but was only approximately $120-130 \mathrm{~nm}$ in width (Fig. 1). A mixture of cell types was observed in the large, grey, spreading colonies, whilst only the thin cell type was observed in the pinpoint colonies. Both cell types had four periplasmic flagella inserted in a row at each end of the cell.

\section{DISCUSSION}

The overall objectives of this study were attained, in that a selective medium was developed and used to isolate $B$. aalborgi from a human faecal sample. This is the first time that this has been achieved, with all isolates previously obtained having been grown directly from biopsy samples. Intestinal biopsies are useful for investigating individual cases of intestinal spirochaetosis, since they can be used to link the presence of spirochaetes to specific pathological changes. Nevertheless, taking biopsies is an invasive process that is only undertaken routinely in developed countries. Collection and examination of faeces for studies on the presence and disease associations of $B$. aalborgi is easier, less expensive and more acceptable to patients. Although the organism can be detected in faeces using PCR (Mikosza et al., 2001b), the ability to culture B. aalborgi will permit future characterization of the isolates and facilitate molecular epi- 


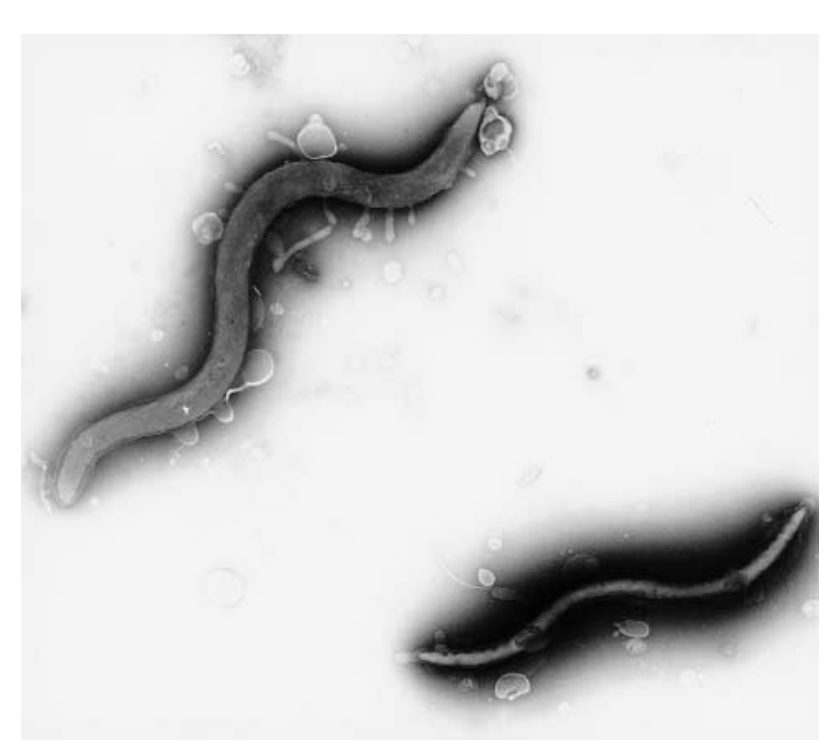

Fig. 1. Electron micrograph showing the two spirochaete cell types isolated from the faeces of a human volunteer. The larger spirochaete cell is $5 \mu \mathrm{m}$ long.

demiology (strain typing) and pathogenicity studies. Hence, the development of an improved selective medium for the isolation of B. aalborgi from human faeces is a useful advance.

The best base medium for growth of $B$. aalborgi was BHIA, supplemented with $10 \% \mathrm{BB}$, whilst selection of B. aalborgi from seeded faeces was achieved with media containing $S$, SC, SP, SR, SRC, SPR, SPC or SRPC. The medium used in previous isolations of $B$. aalborgi was TSA $10 \%$ BB SP (Hovind-Hougen et al., 1982; Kraaz et al., 2000; Jensen et al., 2001). As the performance of these combinations appeared equal in this study, SP was chosen because of the history of successful isolation in previous studies. In this investigation, BHIA $10 \% \mathrm{BB}$ supported better growth than TSA $10 \% \mathrm{BB}$, and it is possible that the additional nutrients provided by the BHIA allowed the B. aalborgi strain that was isolated in this study to out-compete the other gut microbiota on the selective plate.

TSA with $5 \% \mathrm{OB}, \mathrm{S}\left(400 \mu \mathrm{g} \mathrm{ml}^{-1}\right), \mathrm{V}\left(25 \mu \mathrm{g} \mathrm{ml}^{-1}\right)$ and C $\left(25 \mu \mathrm{g} \mathrm{ml}^{-1}\right)$ has been used to isolate B. pilosicoli from human faeces (Lee \& Hampson, 1992). Results from the current study indicate that this medium does not support the growth of $B$. aalborgi, presumably as a result of the strains being susceptible to vancomycin. Poor growth of B. aalborgi W1 on a very similar medium has been reported previously (Kraaz et al., 2000). These results indicate that studies in which TSA $5 \%$ OB SVC is used to isolate human intestinal spirochaetes are likely to fail to isolate $B$. aalborgi.

Pre-reduction of media did not influence growth of $B$. aalborgi; however, tests were carried out on laboratoryadapted strains. It is possible that pre-reduction of media might have allowed the isolation of other strains in the samples tested. Likewise, growth of these strains was barely improved at $38.5{ }^{\circ} \mathrm{C}$, despite a previous report of optimal growth at this higher temperature (Hovind-Hougen et al., 1982). This may again be due to the laboratory adaptation of strains, or the difference observed by Hovind-Hougen et al. (1982) was possibly more marked because of the use of TSA as the base medium. The superior growth achieved in the anaerobic jars compared with an anaerobic chamber was unexpected. Humidity levels tended to be higher in jars, and the gas composition differed between the two atmospheres. In particular, anaerobic jars may contain traces of oxygen, and it is known that the growth of Brachyspira hyodysenteriae is enhanced by the presence of $1 \%$ oxygen, associated with the production of NADH oxidase (Stanton \& Lebo, 1988; Stanton, 1989). B. aalborgi also has a gene encoding NADH oxidase (Mikosza et al., 1999). It is possible that some or all of these factors may have impacted upon growth of B. aalborgi. It is also likely that these organisms are quite sensitive to changes in the environment, as it was noted that growth of $B$. aalborgi was inhibited in the presence of large numbers of contaminating organisms.

Antimicrobial susceptibilities of B. aalborgi were not determined, as growth of the organism was poor and inconsistent on the NCCLS-recommended media for testing anaerobes (Summanen et al., 1993). Results of the disc sensitivity tests did not elicit any more compounds that were considered useful for selective media, as B. aalborgi was susceptible to most compounds tested. Resistance to colistin and rifampicin was already suspected and was thus utilized in this study, and erythromycin is not suitable for use under anaerobic conditions. Demonstration of metronidazole susceptibility at $5 \mu \mathrm{g}$ per disc corresponded to reports of the successful use of this agent in a clinical setting, and this result confirms its role as the drug of choice in intestinal spirochaetosis (Peghini et al., 2000; Heine et al., 2001).

In common with previous descriptions (Hovind-Hougen et al., 1982; Kraaz et al., 2000), two colony types grew from the positive faecal sample. The colony types were similar to those described previously, and the size and morphology of one of the isolates was consistent with previous descriptions of $B$. aalborgi (Hovind-Hougen et al., 1982; Kraaz et al., 2000; Jensen et al., 2001). Sequencing of PCR products from the two colony types gave identical $16 \mathrm{~S}$ rDNA sequences, suggesting that the two types were identical in this region. An unusual feature, however, was the identification of some cells that were much thinner by electron microscopy than the 'typical' cells. The smaller colony types appeared to be made up of these thinner types, although they were also present in the larger colonies. The differences in cell size might have been an artifact, the result of the presence of two distinct types of organism, or might reflect a genuine difference in the phenotype of a given strain. These possibilities require further investigation.

Isolation of B. aalborgi was achieved from only one of five PCR-positive faecal samples. The lower limit of selection from seeded faeces was quite poor, at $2 \times 10^{4}$ c.f.u. (g 
faeces $)^{-1}$, but was comparable to that described for faecal PCR (Mikosza et al., 2001b). While the remainder of these samples may have contained non-viable organisms that therefore were only detected by PCR, these results suggest that further modifications may be required to optimize media and conditions for isolation of all $B$. aalborgi. The individual from whom the $B$. aalborgi isolate was obtained was self-diagnosed as having 'chronic diarrhoea', but was unfortunately lost to follow-up because he moved overseas shortly after the faecal sample was submitted. A faecal sample from his female partner was PCR- and culture-negative for $B$. aalborgi. The availability of an improved isolation medium should now facilitate further epidemiological studies on the possible role of this spirochaete in human colorectal disease.

\section{ACKNOWLEDGEMENTS}

This study was supported by a grant from the National Health and Medical Research Council of Australia. C. J. B. was a recipient of a Murdoch University Research Studentship. Thanks are due to Brian Brestovac and the staff of the PCR laboratory, PathCentre, for sequencing and to Nyree Taylor for providing the reference strains.

\section{NOTE ADDED IN PROOF}

After this paper was accepted for publication, another paper describing the isolation of Brachyspira aalborgi from human faeces was published (Calderaro et al., 2003).

\section{REFERENCES}

Brosius, J., Palmer, M. L., Kennedy, P. J. \& Noller, H. F. (1978). Complete nucleotide sequencing of a $16 \mathrm{~S}$ ribosomal RNA gene from Escherichia coli. Proc Natl Acad Sci U S A 75, 4801-4805.

Calderaro, A., Villanacci, V., Conter, M. \& 12 other authors (2003). Rapid detection and identification of Brachyspira aalborgi from rectal biopsies and faeces of a patient. Res Microbiol 154, 145-153.

Carson, K. C., Meyer, J.-M. \& Dilworth, M. J. (2000). Hydroxamate siderophores of root nodule bacteria. Soil Biol Biochem 32, 11-21.

Crucioli, V. \& Busuttil, A. (1981). Human intestinal spirochaetosis. Scand J Gastroenterol Suppl 70, 177-179.

Douglas, J. G. \& Crucioli, V. (1981). Spirochaetosis: a remediable cause of diarrhoea and rectal bleeding? BMJ (Clin Res Ed) 283, 1362.

Gad, A., Willén, R., Furugård, K., Fors, B. \& Hradsky, M. (1977). Intestinal spirochaetosis as a cause of longstanding diarrhoea. Upsala J Med Sci 82, 49-54.

Harland, W. A. \& Lee, F. D. (1967). Intestinal spirochaetosis. BMJ 3, 718-719.

Heine, R. G., Ward, P. B., Mikosza, A. S. J., Bennett-Wood, V., RobinsBrowne, R. M. \& Hampson, D. J. (2001). Brachyspira aalborgi infection in four Australian children. J Gastroenterol Hepatol 16, 872-875.

Hovind-Hougen, K., Birch-Andersen, A., Henrik-Nielsen, R., Orholm, M., Pedersen, J. O., Teglbjaerg, P. S. \& Thaysen, E. H. (1982). Intestinal spirochetosis: morphological characterization and cultivation of the spirochete Brachyspira aalborgi gen. nov., sp. nov. J Clin Microbiol 16, $1127-1136$.

Jensen, T. K., Boye, M., Ahrens, P., Korsager, B., Teglbjaerg, P. S., Lindboe, C. F. \& Moller, K. (2001). Diagnostic examination of human intestinal spirochetosis by fluorescent in situ hybridization for Brachyspira aalborgi, Brachyspira pilosicoli, and other species of the genus Brachyspira (Serpulina). J Clin Microbiol 39, 4111-4118.

Kraaz, W., Pettersson, B., Thunberg, U., Engstrand, L. \& Fellstrom, C. (2000). Brachyspira aalborgi infection diagnosed by culture and $16 \mathrm{~S}$ ribosomal DNA sequencing using human colonic biopsy specimens. J Clin Microbiol 38, 3555-3560.

Kunkle, R. A., Harris, D. L. \& Kinyon, J. M. (1986). Autoclaved liquid medium for propagation of Treponema hyodysenteriae. J Clin Microbiol 24, 669-671.

Lee, J. I. \& Hampson, D. J. (1992). Intestinal spirochaetes colonizing Aborigines from communities in the remote north of Western Australia. Epidemiol Infect 109, 133-141.

Mikosza, A. S. J. \& Hampson, D. J. (2001). Human intestinal spirochetosis: Brachyspira aalborgi and/or Brachyspira pilosicoli? Anim Health Res Rev 2, 101-110.

Mikosza, A. S. J., La, T., Brooke, C. J., Lindboe, C. F., Ward, P. B., Heine, R. G., Guccion, J. G., de Boer, W. B. \& Hampson, D. J. (1999). PCR amplification from fixed tissue indicates frequent involvement of Brachyspira aalborgi in human intestinal spirochetosis. J Clin Microbiol 37, 2093-2098.

Mikosza, A. S. J., La, T., de Boer, W. B. \& Hampson, D. J. (2001a). Comparative prevalences of Brachyspira aalborgi and Brachyspira (Serpulina) pilosicoli as etiologic agents of histologically identified intestinal spirochetosis in Australia. J Clin Microbiol 39, 347-350.

Mikosza, A. S. J., La, T., Margawani, K. R., Brooke, C. J. \& Hampson, D. J. (2001b). PCR detection of Brachyspira aalborgi and Brachyspira pilosicoli in human faeces. FEMS Microbiol Lett 197, 167-170.

Munshi, M. A., Taylor, N. M., Mikosza, A. S. J., Spencer, P. B. S. \& Hampson, D. J. (2003). Detection by PCR and isolation assays of the anaerobic intestinal spirochete Brachyspira aalborgi from the feces of captive nonhuman primates. J Clin Microbiol 41, 1187-1191.

Padmanabhan, V., Dahlstrom, J., Maxwell, L., Kaye, G., Clarke, A. \& Barratt, P. J. (1996). Invasive intestinal spirochetosis: a report of three cases. Pathology 28, 283-286.

Peghini, P. L., Guccion, J. G. \& Sharma, A. (2000). Improvement of chronic diarrhea after treatment for intestinal spirochetosis. Dig Dis Sci 45, 1006-1010.

Pettersson, B., Wang, M., Fellstrom, C., Uhlen, M., Molin, G., Jeppsson, B. \& Ahrne, S. (2000). Phylogenetic evidence for novel and genetically different intestinal spirochetes resembling Brachyspira aalborgi in the mucosa of the human colon as revealed by $16 \mathrm{~S}$ rDNA analysis. Syst Appl Microbiol 23, 355-363.

Stanton, T. B. (1989). Glucose metabolism and NADH recycling by Treponema hyodysenteriae, the agent of swine dysentery. Appl Environ Microbiol 55, 2365-2371.

Stanton, T. B. \& Lebo, D. F. (1988). Treponema hyodysenteriae growth under various culture conditions. Vet Microbiol 18, 177-190.

Summanen, P., Baron, E. J., Citron, D. M., Strong, C. A., Wexler, H. M. \& Finegold, S. M. (1993). Wadsworth Anaerobic Bacteriology Manual, 5th edn. Belmont, CA: Star.

Trivett-Moore, N. L., Gilbert, G. L., Law, C. L. H., Trott, D. J. \& Hampson, D. J. (1998). Isolation of Serpulina pilosicoli from rectal biopsy specimens showing evidence of intestinal spirochetosis. J Clin Microbiol 36, 261-265.

Weinberg, L. G., Smith, L. L. \& McTighe, A. H. (1983). Rapid identification of the Bacteroides fragilis group by bile disk and catalase tests. Lab Med 14, 785-788. 